DOI: 10.33766/2524-0323.91.239-249

УДК347.440.62:615.038

I. Б. Утехін,

кандидат юридичних наук, доцент, завідувач кафедри фундаментальних юридичних дисциплін

ПВНЗ «Буковинський університет»

(м. Чернівці, Україна)

e-mail: utehin.igor2017@gmail.com

iDhttps://orcid.org/0000-0002-3937-4523

\title{
ДОГОВІР НА ПРОВЕДЕННЯ КЛІНІЧНИХ ВИПРОБУВАНЬ ЛІКАРСЬКИХ ЗАСОБІВ: ПИТАННЯ НАЛЕЖНОЇ КВАЛІФІКАЦЇ
}

У статті визначено відмінні ознаки договору на проведення клінічних випробувань лікарських засобів від суміжних договорів. Він належить до пойменованих договорів. Головна особливість - наявність «етичного» елементу. Це зумовлює його спрямування й зміст. На відміну від мінових договорів, де суть зводиться до товарно-грошового обміну, має місце не комерційний інтерес, а суспільний. Останнє визначає наявність кваліфікаційних ознак такого правочину. Держава зацікавлена в розвитку цих відносин, оскільки йде мова про забезпечення країни необхідними ліками.

Ключові слова: клінічні випробування, договір, предмет договору, зміст договору, етичний елемент, не комерційний інтерес.

Постановка проблеми. Необхідність проведення клінічних випробувань лікарських засобів на сучасному етапі є беззаперечною. Як відомо, в Украӥні більшість лікарських засобів $є$ імпортними. Вітчизняна фармацевтична галузь зацікавлена в збільшенні випуску препаратів. Юридична регламентація процесу проведення клінічних випробувань в Україні здійснена державою. Водночас виникають питання належної правової кваліфікації договору, який є підставою для проведення цих випробувань. Відсутність єдиної судової практики та достатньої кількості наукових досліджень, присвячених договору на проведення клінічних випробувань лікарських засобів, викликають потребу ліквідувати цю прогалину.

Аналіз останніх досліджень і публікацій. У країнах континентального права існує три підходи до розуміння суті договору на проведення клінічних виптробувань лікарських засобів. Так російська цивілістка Н. Г. Балібардіна не відносить його до підрядних договорів, але вважає зобов'язанням з науково-дослідної діяльності, а за спрямованістю результату - до зобов'язань з надання послуг [1, с. 9]. Такий підхід є суперечним.

За наступним підходом, досліднищя І. С. Вороніна дала правову характеристику зазначеному договору і віднесла його до змішаних договорів [2, с. 54]. Це є спірним. Третій підхід, за В. М. Пашковим, полягає в тому, що в господарському законодавстві не міститься спеціальних норм для регулювання відносин у сфері охорони здоров'я я тому всі договори в нійє або комплексними, або змішаними [3, с. 172] Позищія частково схожа з попередньою.

(C) Утехін I. Б., 2020 
За кордоном, зокрема у Великобританії, договір на проведення клінічних випробувань відмежовують від комерційних домовленостей і зазначають про наявність некомерційного ризику та інтересу. Сара Лайтман вказала про п'ять «юридичних пасток», які мають місце в таких відносинах [12]. Погоджуємося, але слід повністю визначити всі конститутивні ознаки договору на проведення клінічних випробувань лікарських засобів.

Формулювання цілей. Відсутність єдиного підходу до розуміння договору на проведення клінічних випробувань лікарських засобів спонукає проаналізувати договір для правильної його кваліфікації і визначення місця серед інших суміжних договірних конструкцій. Зазначене й складає мету цієї статті.

Виклад основного матеріалу. Реалізація принципу «свободи договору» (ст. 627 ЦК України) в сучасних умовах має наслідком виникнення нових договірних конструкцій. Цього вимагають потреби суспільства й учасників цивільно-правових відносин. Договір на проведення клінічних випробувань лікарських засобів відмежовується від традищійних - комутативних контрактів (купівля-продаж, найм, підряд тощо). Він не визначений у Кн. 5 ЦК України, але вказаний у Порядку проведення клінічних випробувань лікарських засобів та експертизи матеріалів клінічних випробувань (п. 9.1.) [7]. Через те його можна вважати пойменованим. Однак дефініція вказаного договору відсутня. Отож потрібно усунути цю прогалину.

Як відомо, в Україні діє Державна стратегія реалізащії державної політики забезпечення населення лікарськими засобами до 2025 року [4]. Цей акт передбачає спосіб введення генериків (похідних препаратів) вітчизняними компаніями після закінчення дії патенту на оригінальний препарат, тому питання клінічних випробувань цих похідних є актуальним.

Російська цивілістка Н. Г. Балібардіна дає авторське визначення вказаного договору, яке містить його основні ознаки: «За договором на проведення клінічних випробувань лікарського засобу виконавець (медична організація), згідно з протоколом клінічного дослідження, зобов' язується провести дослідження (випробування) лікарського засобу з метою отримання науковими методами доказів ефективності та безпеки лікарських засобів, даних про негативні ефекти від застосування лікарських засобів, ефектах взаємодії з іншими лікарськими засобами, а замовник (розробник лікарського засобу чи інша особа, що діє в його інтересах) зобов'язується прийняти результати клінічних досліджень лікарського засобу (науково-обгрунтований звіт) та оплатити їх» [1, с. 9]. У цілому воно є належним і містить основні ознаки цього договору, хоча одночасно є завеликим за обсягом.

Не можна прийняти позицію авторки, яка викладає далі і заперечує те, що вище зазначено. Вона вважає, що зобов' язання з проведення клінічних досліджень лікарських засобів не є ні підрядними, ні «підрядоподібними», ні тими, які до них належать. Таке зобов' язання належить до різновиду науково-дослідницької діяльності, за спрямуванням результату його слід віднести до зобов' язань із надання послуг, серед яких воно посідає самостійне місце» [1, с. 9].

Виникає запитання: якщо це зобов' язання відноситься до різновиду науково-дослідницької діяльності (з цим погоджуємось), то як за спрямуванням результату його це зобов' язання $з$ надання послуг? Відомо, що спрямування зобов' язання з надання 
послуг - надання послуги (ст. 901 ЦК України, ст. 779 ГК РФ). Однак науково-дослідницька діяльність - це не послуга, а інтелектуальна праця (ст. 892 ЦК України, ч. 1 ст. 769 ГК РФ). Можна лише частково погодитися з Н. Г. Балібардіною, що послуга буде, коли надається медична допомога пацієнту чи добровольцю під час проведення клінічного дослідження [1, с. 17]. Тому слід виходити із суті цього договору (з його спрямування) і з його предмету. Далі ми зупинимося на цьому аспекті окремо.

Вітчизняна досліднищя І. С. Вороніна провела правову характеристику договору на проведення клінічних випробувань лікарського засобу. У цілому підхід є правильний. Однак не можна приєднатися до позищії, що цей договір є змішаним, бо поєднує елементи договору на проведення науково-дослідних робіт та договору про надання послуг [2, с. 54]. На наше переконання, узагалі не можна так вважати, оскільки при проведенні клінічних випробувань відбувається виконання завдань, які передбачені протоколом клінічних випробувань. І якщо вказано про клінічні випробування на здорових добровольцях, то не відомі остаточно наслідки цього. Чи потрібна їм буде медична допомога ? Отож договір на проведення клінічних випробувань може бути т. зв. «чистим» - це загальне правило. Розуміємо ситуацію: випробування проводять на здорових добровольцях. У Порядку на проведення клінічних випробувань лікарських засобів вказано, що пацієнт-доброволець - це здорова людина [7]. У другому, змішаному виді, має місце два договори - на проведення науково-дослідної діяльності та надання послуг (ч. 2 ст. 627 ЦК ). Однак за Порядком передбачено лише здорову людину. Тому змішаний характер - виняток.

Слушнимиє зауваження Ю. Павлюченко та О. Антонюк стосовно змісту - умов договору з проведення клінічного випробування, правильності визначення предмету договору [5, с. 54]. Підтримуємо, що тут необхідно виходити із правової природи та сутності договору. Однак, слід більш детально зупинитися на цьому аспекті.

Вважаємо, умова «предмет договору» є системним поняттям, таким, що містить елементи зобов'язання та правочину. Причому вони є взаємопов'язані між собою. Наприклад, якщо уклали договір купівлі-продажу товару, то саме комутативний характер зобов'язань - обмін товару на гроші викликає і вимоги до правочину. Iншими словами, зміст правовідносин зумовлює і форму їх укладання. У випадку з договором на проведення клінічних випробувань лікарських засобів виникають зобов'язання іншого характеру - не комутативного (мінового). Хоча може скластися думка, що це не так.

Слід погодитися з позищією доцента М. М. Гудими: «Умова про предмет договору - єдина, яка віднесена законодавцем до істотних стосовно будь-якого договору визначає характер самого договору і відрізняє в цілому всю систему договірних відносин» [6, с. 94].

Як відомо, суть договору міститься в його істотних умовах. Тому згідно з ч.1 ст. 638 ЦК, договір є укладеним, якщо сторони в належній формі досягли згоди 3 усіх істотних умов договору. Абз. 2 цієї ж частини вказує: «Істотними умовами договору є умови про предмет договору, умови, що визначені законом як істотні або є необхідними для договорів даного виду, а також усі ті умови, щодо яких за заявою хоча б однієї із сторін має бути досягнуто згоди». Зазначені положення можна вважати алгоритмом існування будь-якого цивільно-правового договору. 
Вважаємо, що цей договір є різновидом договору на проведення науково-дослідних робіт. Відповідно до положень Гл. 62 ЦК, істотними умовами договору на проведення науково-дослідних робіт є: 1) предмет - визначення тої роботи; яку слід виконати; 2) строк виконання; 3) ціна за роботу; 4) права на використання результату науково-дослідної роботи.

Водночас, договір на проведення клінічних випробувань лікарських засобів має свої особливості, які відмежовують його від звичайних видів договорів на проведення науково-дослідних робіт. Якщо звернути увагу на його назву, то стає зрозумілим, про що йде мова: про законне втручання особисту сферу людини, ії життя і здоров'я. Як передбачено в ст. 3 Конституції України: «Людина, іiї життя і здоров'я, честь і гідність, недоторканість і безпека вважаються в Україні найвищою соціальною цінністю». Тому й має місце особливий вид договірних відносин, відмінний від звичайних (комутативних) договорів.

Як передбачено в Державній стратегії, одним із шляхів розв' язання проблем у сфері розробки та дослідження лікарських засобів є розроблення пропозищій про внесення змін до нормативно-правових актів, настанов та методичних рекомендацій щодо різних видів клінічних випробувань [4].

Відповідно до вказаного, доцільно розробити окрему методику з укладання договору на клінічні випробування лікарських засобів на рівні Міністерства охорони здоров' я України.

Для розуміння природи договору на проведення клінічних досліджень лікарських засобів необхідно дати відповідь на питання, чи є він комутативним (міновим). Як відомо, останній передбачає обмін товару на гроші. До них належать цивільноправові договори різних типів, що забезпечують товарно-грошовий обіг у суспільстві: купівля-продаж, найм (оренда), підряд, послуги. Усі вони мають спільну рису: такі договори задовольняють потреби фізичних, юридичних осіб, держави. Ці потреби є матеріальними чи нематеріальними. Вважаємо, що договір на проведення клінічного випробування лікарського засобу відмежовується від звичайних, мінових договорів. Справа в тому, що, на відміну від договору купівлі-продажу, де покупець, придбавши річ, яку необхідно, і ставши їі власником, задовольняє свій інтерес (приватний). За договором про клінічні випробування лікарського засобу потреба не приватна (частково), а в основному суспільна (потреба в лікуванні). Слід зазначити, що у Великобританії також відмежовують проведення клінічних випробувань від комерційної угоди, оскільки має місце некомерційний ризик та інтерес [12].

Завданням держави є збереження здоров'я населення країни. І тут вона має інтерес у тому, щоби цього досягати найкращим і білыш раціональним способом.

Усе вказане вище спрямовує нас до питання «предмет договору». Вважаємо, предмет договору на клінічні випробування лікарських засобів необхідно розглядати з позищії «людиноцентричної». Цей підхід було запропоновано С. О. Почтарьовим при аналізі договору дарування [8, с. 12].

Стосовно нашого випадку, перевагу має складати не грошова винагорода, а саме користь для суспільства певного лікарського засобу. Особливо яскраво це виявляється в наш час, коли існує пандемія коронавірусу. Учені всього світу працюють над створенням вакцини від хвороби. На сьогодні у світі працює тридцять п' ять ла- 
бораторій. Вони дбають не про те, щоб заробити, а про безпеку всіх людей. Матеріальне не мусить переважати над моральними нормами! Саме етичний характер цього правочину і відрізняе його від традищійних мінових контрактів. Слід вважати це «етичним елементом» договору на проведення клінічних випробувань лікарського засобу (курсив від автора - І. Б.). Без нього не можливе все інше. Маємо справу із здоров'ям і життям людини. Водночас, у світі вже підрахували прибуток від вакцини - тридцять п'ять мільярдів доларів. Однак мета інша - зберегти життя та здоров'я людей.

Сучасна англійська дослідниця Сара Ліман назвала «відповідальність й етичний бік» четвертим «підводним камінцем» у клінічних випробуваннях [12]. Вона слушно вказала, що етичний бік має місце й при використанні персональних даних добровольців-пацієнтів [12]. Іншими словами, з п' яти «правових пасток», які виникають при клінічних випробуваннях, дві з них пов'язані саме з етичним елементом. I їх слід вважати головними.

Передумовою проведення клінічного випробування є згода пацієнта, яка має бути добровільною. Це викликано тим, що фізична особа дає дозвіл на втручання в їі організм. Примусити до цього не можна. Лише добровільна згода (ч. 3 ст. 281 ЦК). Через те показовим є приклад співробітників державної наукової установи «Вектор» (РФ), які виявили бажання бути пацієнтами при клінічних випробуваннях препарату проти коронавірусу, який вони самі й розробили. Метою цього також є зменшення часу на пошук добровольців для проведення досліджень. Головне - мова йде про власне бажання людини-пацієнта, яка буде брати участь у клінічному випробуванні.

18 червня 2020 року в РФ приступили до клінічних випробувань ліків від коронавірусу. 14 липня заявили про успішне проведення клінічного випробування необхідної вакцини від COVID-19. 20 липня в РФ були виписані добровольці, які успішно пройшли клінічні випробування вакцини від COVID-19. На сьогодні у світі тривають клінічні випробування інших препаратів проти нового вірусу. Таким чином, процес цих випробувань $є$ соціально зумовленим та стратегічно необхідним для кожної країни світу.

Отже, договір, який ми аналізуємо, посідає окреме місце в системі договірного права. Він спрямований на проведення науково-дослідних робіт і $є$ його різновидом (Гл. 62 ЦК). Однак, це особливий договір і відмінний від інших видів науково-дослідних робіт. Перш за все, це викликано його суттю - втручанням в організм людини. Саме тому він окремо регламентується в законодавстві про охорону здоров'я України $[9,10,7]$.

За законодавством Великобританії, цей договір урегульований типовою угодою, затвердженою Урядом, а також законодавством ЄС (Директива 200/20 EC) (Clinical Trials Derective) та Загальною постановою про захист персональних даних [12].

В Україні більш детально передбачено не все, а лише п'ять пунктів у Порядку проведення клінічних випробувань лікарських засобів та експертизи клінічних матеріалів. Такий стан не $є$ належним, тому слід внести відповідні зміни й доповнення. Зокрема, у Порядку можна було б передбачити окремий розділ, присвячений договору на проведення клінічних випробувань, де вказати його дефініцію, істотні умови, права та обов'язки сторін, форму. Також доцільно передбачити в окремому 
додатку типовий договір на проведення клінічних випробувань лікарських засобів, як це має місце у Великобританії та інших країнах СС.

На наш погляд, це б дозволило впорядкувати ситуацію з укладанням і виконанням таких важливих договорів. Дія принципу «свободи договору» (ст. 627 ЦК) в цьому випадку має бути обмежена на користь безпеки для життя і здоров'я людини, хоча в судовій практищі ії не обмежують. Показовим прикладом є рішення по адміністративній справі № 1840/3701/18, котру розглянув Сумський окружний адміністративний суд. Він не заперечив укладання шістьох договорів на проведення клінічних випробувань, де стороною-дослідником була фізична особа-підприємець, а замовником - не резидент. Було правильно вказано, що виконання цих договорів не привело до нового наукового результату, клінічне випробування (дослідження) лікарського засобу - науково-дослідницька робота. Фактично це були договори на передачу майнових прав інтелектуальної власності [11]. Будь-який учасник цивільних відносин не може укладати договір як дослідник на проведення клінічних випробувань. Це випливає з Порядку на проведення клінічних випробувань лікарських засобів та експертизи клінічних матеріалів [7]. Отже, судова інстанщія виходила зі змісту вказаних договорів, а не з їх назви.

3 огляду на вказане, предметом договору на проведення клінічних випробувань лікарських засобів слід вважати проведення клінічних випробувань певного лікарського засобу, що є науково-дослідною роботою. Його зміст, як випливає із протоколу клінічного випробування, містить комплекс із 7 елементів: завдання, методологія, процедура, статистичні аспекти та організація клінічного випробування, раніше отримані дані щодо досліджуваного лікарського засобу та обгрунтування клінічного випробування (п. 2.1) [7]. Це означає, що умова «предмет» визначена імперативно. Зміна її чи відхилення від неї вважається порушенням договору на клінічні випробування (п. 2.1) [7]. Слід наголосити, що такий стан, коли саме протокол клінічних досліджень усе містить, має місце й у ЄС [12]. І все перелічене дає підставу стверджувати, що предмет договору на проведення клінічних випробувань лікарського засобу є складним.

Це вказує на особливості, відмінності нашого договору від комутативних договорів, де діє в повній мірі принщип «свободи договору» ст. 627 ЦК. Маємо приклад винятку, коли переймаються не матеріальною стороною, а нематеріальним - збереженням життя та здоров'я людей. Отож, на відміну від комутативного контракту, де сторони мають право змінювати на свій розсуд його зміст, відповідно до ст. 6 ЦК, за договором на проведення клінічних випробувань лікарського засобу це $є$ не можливим, оскільки суперечить його суті - втручанню в особисту сферу людини. Відповідальний дослідник, дослідник може відхилитися від протоколу клінічного випробування лише в разі необхідності усунення небезпеки, що безпосередньо загрожує досліджуваним, без попереднього затвердження Центром (п. 9.5.) [7].

Перейдемо до розгляду ознак зазначеного договору. Традищійно ознаки виводять із дефініції того чи іншого договору. Вище ми зазначили про наявність авторського визначення вказаного договору. Однак, воно є великим за обсягом, громіздким. Тож пропонуємо власну дефініцію: «За договором на проведення клінічних випробувань лікарських засобів одна сторона - виконавець - зобов'язується провести 
клінічні випробування певного лікарського засобу на замовлення замовника відповідно до вимог чинного законодавства України. Замовник має прийняти результат досліджень і сплатити визначену ціну».

Визначення містить основні ознаки таких договірних відносин. Це:

а) особливі відносини з етичним елементом; б) різновид договору 3 проведення науково-дослідних робіт; в) предмет - виконання клінічних випробувань лікарського засобу; г) є не міновий договір у прямому розумінні; д) врегулювання як цивільним законодавством, так й окремими актами у сфері охорони здоров'я (змішане врегулювання). Через те слід пригадати позицію про змішаний характер договору, що розглядається. Вважаємо, має місце саме змішане правове регулювання (різні нормативні акти), а не характер цього договору. Як відомо, змішаний договір це той, що містить елементи різних договорів.

Окрім того, наведена дефініція договору дозволяє дати і його характеристику як правочинну та зобов' язання. Це є консенсуальний договір - вважається укладеним $з$ моменту досягнення згоди 3 його істотних умов. Через те що вони окремо не визначені в законодавстві, встановимо їх: а) предметом договору є клінічні випробування лікарського засобу; б) порядок проведення клінічних випробувань (за протоколом); в) строк досліджень; г) ціна; д) страхування життя і здоров'я пацієнта.

Як було вказано вище, укладанню договору передує ряд дій, які вчиняються перед цим. Має місце складний юридичний факт - юридичний склад. Передбачено три етапи: 1) прийняття рішення ЦОВВ; 2) отримання протоколу(ів) комісії(й) із питань етики при ЛПЗ; 3) укладення договору про страхування життя і здоров'я пацієнта (доброволыц). Без проведення всіх формальностей розпочинати клінічні випробування не можливо (п. 3.5.) [7]. Це ще раз підтверджує особливість вказаного правочину і відмінність від звичайних правочинів. Усе міститься в предметі такого договору й далі визначає його наступну ознаку - фідуціарність.

Мова йде про довіру пацієнта до тих, хто буде проводити випробування. Немає довіри - немає договору на клінічні випробування. Як відомо, питання довіри пацієнта існує як до, так і під час випробувань (курси від автора - І. Б.). Діє комісія 3 питань етики при закладі охорони здоров'я чи лікувально-профілактичному закладі. Вона здійснює нагляд за дотриманням прав, безпекою, благополуччям досліджуваних пацієнтів, етичних та морально-правових принципів проведення клінічного дослідження (п. 2.1.) [7].

Договір є двох- чи багатостороннім, бо зобов' язання на боці дослідника(ків), замовника. У пацієнта зобов' язань немає - лише права. Сдине - він має виконувати вказівки дослідника(лікаря). Тому основні обов'язки покладаються на виконавця(ців) клінічних випробувань.

Договір є алеаторним (ризиковим), оскільки заздалегідь невідомо, як закінчиться клінічне випробування лікарського засобу. У Порядку на проведення клінічних випробувань лікарських засобів та експертизи матеріалів клінічних випробувань наголошено, що клінічне випробування може проводитися тільки в тому випадку, якщо очікувана користь виправдовує ризик (п. 3.1.) [7]. У комерційних договорах існує ризик, який пов'язаний із підприємництвом. У договорі на проведення клінічних випробувань лікарського засобу ризик зовсім відмінний. Користь від випробування має бути більшою за ризик, який існує при цьому. 
При проведенні клінічних випробувань гарантувати стовідсотковий позитивний результат не можуть. До речі, це іє прояв суті науково-дослідних робіт (ст. 899 ЦК). Хоча, навпроти, у клінічних випробуваннях усе відбувається згідно з протоколом. Можна вважати, існує певний алпоритм проведення клінічного випробування, на відміну від науково-дослідних робіт, де дослідник має власні методи проведення дослідження (ст. 897 ЦК). На наше переконання, це доводить, що білыше творчості в останньому, у клінічному - навпаки. Причиноює те, що мова йдепро життя іздоров' япацієнта. Зайві ризики тут не припустимі. Через це пацієнт підлягає страхуванню.

І ще один доказ алеаторності. У п. 1.8. Порядку проведення клінічних випробувань зазначено: «Якщо в період проведення клінічного випробування відбувається подія, пов' язана з проведенням клінічного випробування або розробкою досліджуваного лікарського засобу, яка здатна вплинути на безпеку досліджуваних, спонсор та/або дослідник здійснюють негайні заходи для забезпечення безпеки досліджуваних» [7].

Договір є строковим - випробування мають свій час. Договір є оплатний - за виконання клінічного випробування передбачається оплата. Також самі добровольці можуть отримати винагороду після проведення випробувань. Зокрема, у Росії добровольцям, які пройшли випробування вакцини від Ковіду виплатять по 100000 рублів. Отож, на відміну від звичайних (мінових) контрактів, у клінічних випробуваннях передбачається виплата особам, які ризикували життям і здоров' ям. Це компенсація за їхню сміливість. Як указувалося вище, договір на проведення клінічних випробувань лікарських засобів може бути двох видів: а) суто на проведення клінічних випробувань; б) змішаним - коли мають місце елементи договору на проведення науково-дослідних робіт та надання послуг.

Усі ці ознаки й характеристика договору відмежовує його від інших відомих договірних конструкцій, визначає власне місце серед видів договору на проведення науково-дослідних робіт (ст. 892 ЦК).

Висновки. Підсумовуючи, можна зазначити, що «етичний» елемент договору на проведення клінічних досліджень є логічним віддзеркаленням суті таких відносин, оскільки клінічне дослідження - то дослідження на організмі людини. Саме це і відмежовує його від інших договорів на проведення науково-дослідних робіт і комерційних контрактів. Зазначене враховане вітчизняним законодавцем у нормативних актах про охорону здоров' я. Договір на проведення клінічних випробувань посідає самостійне місце серед суміжних договорів. Має відмінності та особливості змісту. Предметом договору на проведення клінічних випробувань лікарських засобів слід вважати проведення клінічних випробувань певного лікарського засобу, що є науково-дослідною роботою.

Предмет договору на проведення клінічних випробувань лікарського засобу є складним. Послуга не може бути окремим предметом, а лише спільно 3 науково-дослідною роботою. На відміну від комутативного контракту, де сторони мають право змінювати на свій розсуд його зміст, відповідно до ст. 6 ЦК, за договором на проведення клінічних випробувань лікарського засобу це є не можливим, оскільки суперечить його суті - втручанню в особистий простір людини. Дію принщипу «свободи договору» обмежено інтересом добровольця-пацієнта. Істотні умови цього договору 
формуються під впливом імперативних положень чинних нормативних актів. Судова практика правильно кваліфікує ці договірні відносини. Водночас, необхідно вдосконалювати механізм правового регулювання вказаних відносин в Украӥні для захисту інтересів усього суспільства й держави. Зокрема, пропонуємо доповнити нормативну базу легальним визначенням договору на проведення клінічних випробувань лікарського засобу. Отже, надалі логічним буде висвітлення питання виконання за договором, який ми розглянули.

\section{Використані джерела:}

1. Балибардина Н. Г. Договор на проведение клинических исследований лекарственньхх средств: автореф.: дис... к.ю.н. 12.00.03. Волгоград, 2006. 22 с.

2. Вороніна I. С. Характеристика договору на проведення клінічного випробування лікарського засобу для застосування людиною. Право і суспільство. № 6-2, частина 3. 2015. С. 50-55.

3. Пашков В. М. Проблеми правового регулювання відносин у сфері охорони здоров'я (господарсько-правовий контекст). Київ: Моріон, 2009. 448 с.

4. Державна стратегія реалізації державної політики забезпечення населення лікарськими засобами до 2025 року. Затверджена постановою Кабінету Міністрів України від 5 грудня 2018 р. № 1022. URL://https://zakon.rada.gov.ua/laws/show/10222018-п\#Техt. (дата звернення 23.07.2020)

5. Павлюченко Ю. О. Антонюк Умови договорів щодо проведення клінічних випробувань. Підприємництво, господарство і право. № 3. 2019. С. 52-56.

6. Гудима М. М. Визначення предмету договору про надання туристичних послуг. Актуальні проблеми вдосконалення чинного законодавства України. 2010. Вип. 22. С. 94-100.

7. Порядок проведення клінічних випробувань лікарських засобів та експертизи клінічних матеріалів. URL:https://zakon.rada.gov.ua/laws/show/z1010-09\#n16.

8. Почтарьов С. О. Договір дарування в цивільному праві та в нотаріальній діяльності: автореф. дис. ... к.ю.н. 12.00.03. Київ, 2015. 20 с.

9. Основи законодавства України «Про охорону здоров'я». URL:https:// zakon. rada.gov.ua/laws/show/2801-12

10. Закон України «Про лікарські засоби». URL:https:/ /zakon.rada.gov.ua/ laws/ show/123/96-вр\#n13. (дата звернення 23.07.2020)

11. Рішення адміністративного суду Сумської області № 1840/3701/18 від 01.02.2019 URL:https:/ / zakononline.com.ua/court-decisions/show/800552201. (дата звернення 23.07.2020)

12. Sarah Lyman The five legal pitfalls of clinical trail agreements. URL: https://pharmafield.co.uk/opinion/the-five-legal-pitfalls-of-clinical-trial-agreements. (дата звернення 23.07.2020)

\section{References:}

1. Balibardina, N. G. (2006) Dogovor na provedenie klinicheskikh issledovaniy lekarstvennykh sredstv. Extended abstract of candidate's thesis. Volgograd. [in Russian].

2. Voronina, I. S. (2015) Kharakterystyka dohovoru na provedennia klinichnoho vyprobuvannia likarskoho zasobu dlia zastosuvannia liudynoiu. Pravo i suspilstvo-Law and society, 6-2, part. 3, 50-55. [in Ukrainian]. 
3. Pashkov, V. M. (2009) Problemy pravovoho rehuliuvannia vidnosyn u sferi okhorony zdorov'ia (hospodarsko-pravovyi kontekst). Kyiv: Morion. [in Ukrainian].

4. Derzhavna stratehiia realizatsii derzhavnoi polityky zabezpechennia naselennia likarskymy zasobamy do 2025 roku. Zatverdzhena postanovoiu Kabinetu Ministriv Ukrainy vid 5 hrudnia 2018 r. № 1022. (2018) N. p. URL:https://zakon.rada.gov.ua/ laws/show/ 1022-2018-p\#Text. [in Ukrainian].

5. Pavliuchenko, Yu. O. (2019) Antoniuk Umovy dohovoriv shchodo provedennia klinichnykh vyprobuvan. Pidpryiemnytstoo, hospodarstvo i parvo - Entrepreneurship, economy and law, 3, 52-56. [in Ukrainian].

6. Hudyma, M. M. (2010) Vyznachennia predmetu dohovoru pro nadannia turystychnykh posluh. Aktualni problemy vdoskonalennia chynnoho zakonodavstva Ukrainy-Current problems of improving the current legislation of Ukraine, issue 22, 94-100. [in Ukrainian].

7. Poriadok provedennia klinichnykh vyprobuvan likarskykh zasobiv ta ekspertyzy klinichnykh materialiv. N. p. N. d. URL:https://zakon.rada.gov.ua/laws/show/z101009\#n16. [in Ukrainian].

8. Pochtarov, S. O. (2015) Dohovir daruvannia v tsyvilnomu pravi ta v notarialnii diialnosti. Extended abstract of candidate's thesis. Kyiv. [in Ukrainian].

9. Osnovy zakonodavstva Ukrainy «Pro okhoronu zdorov'ia». N. p. N. d. URL:https:/ / zakon.rada.gov.ua/laws/show/2801-12. [in Ukrainian].

10. Zakon Ukrainy «Pro likarski zasoby». N. p. N. d. URL:https://zakon.rada.gov. ua/laws/show/123/96-vr\#n13. [in Ukrainian].

11. Rishennia administratyvnoho sudu Sumskoi oblasti №1840/3701/18 vid 01.02.2019. (2019) N.p. URL:https:/ /zakononline.com.ua/court-decisions/show/800552201. [inUkrainian].

12. Sarah Lyman The five legal pitfalls of clinical trail agreements. N. p. N. d. URL:https://pharmafield.co.uk/opinion/the-five-legal-pitfalls-of-clinical-trial-agreements. [in Ukrainian].

Стаття надіӥшла до редколегї 03.08.2020

Утехин И. Б., кандидат юридических наук, доцент, заведующий кафедрой фундаментальных юридических дисциплин

ЧВУЗ «Буковинский университет»

(г. Черновцы, Украина)

\section{ДОГОВОР НА ПРОВЕДЕНИЕ КЛИНИЧЕСКИХ ИСПЫТАНИЙ ЛЕКАРСТВЕННЫХ СРЕДСТВ: ВОПРОС НАДЛЕЖАЩЕЙ КВАЛИФИКАЦИИ}

В статье установлены отличия договора на проведение клинических испытаний лекарственных средств. Несмотря на то что он относится к поименованным договорам и упомянут в подзаконном нормативном акте, легальная дефиниция в украинском законодательстве отсутствует. Этот договор является видом договора на проведение научно-исследовательских работ, однако имеет собственные особенности. Прежде всего, это его направленность на проведение клинических испытаний. Наличие «этического» элемента определяет его дальнейшее регулирование и кардинальное отличие от меновых договоров. 
Ключевые слова: клинические испытания, договор на проведение научно-исследовательских работ, «этический» элемент, не коммерческий характер, предмет договора, содержание договора.

\section{Utekhin I., \\ Candidate of Law, Associate Professor, Head of the Department of Fundamental Legal Disciplines PHEI Bukovynian University (Chernivtsi, Ukraine)}

\section{CONTRACT FOR CONDUCTING CLINICAL TRIALS OF MEDICINES: ISSUES OF APPROPRIATE QUALIFICATION}

The contract for clinical trials of drugs occupies an independent place among the known contract designs. It is concluded for a clinical trial. This means the study of certain drugs in the human body. This is what determines its legal purpose. Signs that distinguish this agreement are as follows. This is a named contract, a kind of contract for research. However, this is a special agreement. It contains an "ethical" element. The tests involve the intervention of a volunteer patient. That's why protecting his life and health is paramount. Unlike commercial contracts where they care about profits. Therefore, the regulation of these relations is separate. This is provided for in bylaws. The principle of "freedom of contract" in this case is limited. The parties must comply with the law. Which is an exception to the general rule. The state is interested in the development of these contractual relations.

We consider the "ethical" element as the first qualifying feature of the contract for clinical trials of drugs. He first indicates the essence of the transaction. Secondly, it is a prerequisite for any clinical trials of drugs. Third, it remains valid both during and after the tests. If the volunteer patient does not want to participate in the trials, it is his right.

This agreement has a clear procedure for concluding. Until then, a preparatory stage is required. The content of the contract is determined by law. Everything is due to the protection of the interests of the patient-volunteer.

We offer the author's definition of the contract for clinical trials of drugs. It contains all the main features that distinguish it. Next, we characterize this agreement: consensual, bilateral (multilateral), paid, fiduciary, aleatory, with ethical content. Based on this, this agreement is an independent named agreement. It belongs to the contracts for research work. It has features of subject composition, subject, content.

The contract for clinical trials of medicinal products occupies an important place in the contract law system. It differs significantly from other contractual designs. Acts in the field of ethical relations, which determines its essence. This is an example of how the ethical nature of a relationship affects legal regulation.

The value of human life and health is confirmed. In the future, it is necessary to consider the performance under the contract for the conduct of clinical trials of drugs.

Keywords: clinical trials, contract, ethical element, subject of the contract, content of the contract, research work. 